\title{
Non-Dispersive Extraction of Ge(IV) from Aqueous Solutions by Cyanex 923: Transport and Modeling Studies
}

\author{
Hossein Kamran Haghighi ${ }^{1}\left(\mathbb{D}\right.$, Mehdi Irannajad ${ }^{1, *}\left(\mathbb{C}\right.$, Maria Teresa Coll ${ }^{2}$ and \\ Ana Maria Sastre ${ }^{3}$ (D) \\ 1 Department of Mining and Metallurgical Engineering, Amirkabir University of Technology, \\ Tehran 1591634311, Iran; h.kamran.h@aut.ac.ir \\ 2 Department of Chemical Engineering, Universitat Politècnica de Catalunya, EPSEVG, \\ Av. Víctor Balaguer s/n, 08800 Vilanova i la Geltrú, Spain; m.teresa.coll@upc.edu \\ 3 Department of Chemical Engineering, Universitat Politècnica de Catalunya, ESTEIB, Av. Diagonal 647, \\ 08028 Barcelona, Spain; ana.maria.sastre@upc.edu \\ * Correspondence: iranajad@aut.ac.ir; Tel.: +98-21-6454-2937
}

Received: 27 May 2019; Accepted: 7 June 2019; Published: 11 June 2019

\begin{abstract}
Transport process of germanium from an aqueous solution containing oxalic acid and $100 \mathrm{mg} / \mathrm{L}$ Ge was studied. Cyanex 923 immobilized in a polytetrafluoroethylene membrane was employed as a carrier in a flat-sheet supported liquid membrane (FSSLM) system. The speciation of the germanium ion in the oxalic acid medium and related diagrams were applied to study the transport of germanium. The effective parameters such as oxalic acid, carrier concentration, and strip reagent composition were evaluated in this study. Based on the experimental data, the oxalic acid and carrier concentrations of $0.075 \mathrm{~mol} / \mathrm{L}$ and $20 \% \mathrm{v} / \mathrm{v}$ were the condition in which the efficient germanium transport was achieved, respectively. The concentration range of $0.04-0.1 \mathrm{~mol} / \mathrm{L}$ was selected for sodium hydroxide $(\mathrm{NaOH})$ as a strip reagent providing the best efficiency to transport germanium through the supported liquid membrane (SLM) system. Furthermore, the permeation model was obtained to calculate the mass transfer resistance of the membrane $\left(\Delta_{m}\right)$ and feed $\left(\Delta_{f}\right)$ phases. According to the results, the values of 1 and $1345 \mathrm{~s} / \mathrm{cm}$ were found for $\Delta_{m}$ and $\Delta_{f}$, respectively.
\end{abstract}

Keywords: germanium; supported liquid membrane; transport; Cyanex 923; modeling

\section{Introduction}

Germanium is a strategic metalloid mainly used in a wide range of high-technology devices [1]. Germanium is found in lead-zinc ores [1] and coal fly ashes [2]. From the perspective of hydrometallurgy, the leach solutions obtained from zinc plant residues and coal fly ashes contain germanium along with the other metals. The most important elements that can be found in these solutions are heavy metals such as zinc, nickel, cobalt, cadmium [3,4]. The germanium separation from these solutions is a vital objective in obtaining purified germanium.

Gasification coal fly ashes (GCFAs) containing germanium can be leached with water to dissolve germanium as water-soluble species [5]. Several processes have been developed to recover and separate germanium from impurities such as precipitation [6], flotation [7], ion-exchange [8], distillation [2], adsorption [9], liquid-liquid extraction (LLX) [10], and supported liquid membrane (SLM) [11-13]. Among these techniques, the LLX processes have been extensively applied to separate germanium from aqueous solutions [3,14]. However, some disadvantages such as high loss of extractant, high capital cost, and difficult operation make this method inappropriate for treating low concentrations of ions. The supported liquid membrane techniques have been introduced as alternative methods to 
overcome these disadvantages [15]. High selectivity, easy operation, low consumption of carrier, and the one-step process are some advantages of SLMs [16-19].

Liu et al. [1] reported oxalic acid as an efficient reagent to dissolve germanium from zinc residues. Therefore, one of the important leachates containing germanium is oxalate solution. To separate germanium from this type of solution, a few studies have been carried out. Liquid-liquid extraction of germanium from zinc leachates containing oxalic acid solutions has been carried out using tertiary amines [20,21]. Since species of germanium oxalates are in the neutral form $\left(\mathrm{H}_{2} \mathrm{Ge}\left(\mathrm{C}_{2} \mathrm{O}_{4}\right)_{3}\right)$ [14], it was anticipated that a neutral extractant could be used to extract germanium. In this regard, Cyanex 923 (a mixture of four trialkylphosphine oxides, alkyl = normal, $\mathrm{C}_{6}, \mathrm{C}_{8}$ [22]) with solvation extraction behavior was selected. Solvent extraction experiments using Cyanex 923 showed good efficiency for the extraction of germanium from oxalate solutions [14]. To overcome the challenges mentioned for an LLX system, an SLM system containing Cyanex 923 was firstly developed to transport germanium from an oxalate solution.

Cyanex 923 has been widely used in SLM systems. The permeation of cadmium $\left(\mathrm{H}_{(\mathrm{n}-2)} \mathrm{CdCl}_{n}\right)$ from wastewater containing chloride anions has been investigated through SLM processes using Cyanex 923 [23]. Chromium(VI) neutral species $\left(\mathrm{H}_{2} \mathrm{CrO}_{4}\right)$ were transported across an FSSLM system using Cyanex 923 from chloride solutions [24]. Zinc(II) species in the form of $\mathrm{H}_{n} \mathrm{ZnCl}_{(2+n)}$ were permeated by a solid-SLM from chloride medium using Cyanex 923 [25]. In addition, an FSSLM system has been used to transport $\mathrm{HFeCl}_{4}$ species through a polyvinylidene difluoride (PVDF) membrane with the carrier of Cyanex 923 from a solution containing chloride ions [26]. Alguacil et al. [27] investigated the transport of $\mathrm{Au}(\mathrm{III})$ in the form $\mathrm{HAuCl}_{4}$ through a PVDF membrane film impregnated in Cyanex 923 from an $\mathrm{HCl}$ solution. Results showed good transport efficiency for gold species. Neutral complexes of uranium(VI) $\left(\mathrm{UO}_{2}\left(\mathrm{H}_{2} \mathrm{PO}_{4}\right)_{2}\right)$ were separated through an SLM system from phosphoric acid solutions using the mobile carriers containing 2-ethyl hexyl phosphoric acid mono-2-ethyl hexyl ester (PC88A) and Cyanex 923 [28].

The presented research describes a flat-sheet supported liquid membrane (FSSLM) process with a Cyanex 923 carrier, in which the facilitated transport of germanium species is carried out from a solution containing oxalic acid. Significant parameters affecting the transport of germanium such as germanium concentration in the feed phase, carrier composition, oxalic acid concentration, membrane type, and $\mathrm{NaOH}$ concentration in the strip phase have been investigated in detail. Finally, a mass transfer model was developed to find $\Delta_{a q}$ and $\Delta_{\text {org }}$ values which are the resistances corresponding to the species diffusion through the feed-membrane interfacial layer and membrane phase, respectively.

\section{Experimental Section}

\subsection{Materials}

Cyanex 923 (93\%) consisting of a mixture of four trialkylphosphine oxides (alkyl = normal, $\mathrm{C}_{6}$, $\mathrm{C}_{8}$ ) was supplied by CYTEC Inc., NJ, USA. Various concentrations of Cyanex $923(5-30 \% \mathrm{v} / \mathrm{v})$ as a carrier were prepared by dissolving it in kerosene (Sigma-Aldrich, MO, USA). In all experiments, purified water was supplied through a water purifier (Siemens, Germany). Water solutions used in this study contained $100 \mathrm{mg} / \mathrm{L}$ of germanium ion which were prepared by dissolving $\mathrm{GeO}_{2}(99.99 \%)$ from Sigma-Aldrich. Desired amounts of oxalic acid powder, from Panreac, Barcelona, Spain, were added to the aforementioned solutions to obtain different oxalate concentrations in the range of $0.05-0.2 \mathrm{~mol} / \mathrm{L}$. Sodium hydroxide $(\mathrm{NaOH})$ was used to prepare stripping solutions.

Poly tetra fluoro ethylene (PTFE) and polyvinylidene difluoride (PVDF) flat-sheet hydrophobic membranes with the characteristics being porosity of about $85 \%, 47 \mathrm{~mm}$ diameter, pore size of $0.45 \mu \mathrm{m}$, and diameter of $47 \mathrm{~mm}$ from Millipore, KGaA, Darmstadt, Germany, were used in the present study as a liquid membrane support. 


\subsection{Membrane Experiments}

FSSLM experiments were carried out in a system including two cells attached together with a flanged chamber between the cells in which a membrane filter could be placed. The effective membrane area was calculated to be $11 \mathrm{~cm}^{2}$. The configuration of this system has been shown as Figure 1 . To prepare membranes for experiments, PTFE membranes were immersed in Cyanex 923 solutions for $30 \mathrm{~min}$. The carrier molecules fill membrane pores by capillarity during this time. Afterward, the membrane was taken out from a Cyanex 923 solution and it was washed with water to remove the carrier excess. Finally, the membrane was placed between two cells. The samples, with volumes of $0.5 \mathrm{~mL}$ from both cells, were taken to evaluate the concentration of the metal ions during the experiments. The composition of solutions was determined using inductively coupled plasma atomic emission spectroscopy (ICP-AES Agilent, Santa Clara, CA, USA). The reproducibility of experimental values was calculated in the range of $\pm 5 \%$ and illustrated as error bars in the next figures.

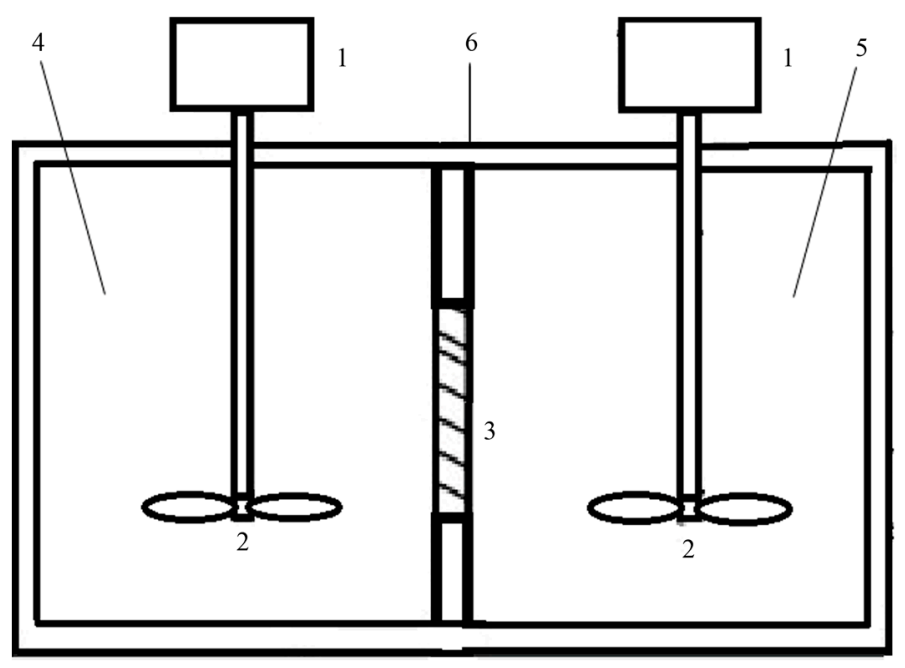

Figure 1. Flat-sheet supported liquid membrane (FSSLM) system used in the current study. 1: Motors, 2: agitators, 3: flat-sheet membrane chamber, 4: feed phase, 5: strip phase, 6: Plexiglass body.

\subsection{Transport Equations}

Transport phenomena in SLM processes principally occur in three steps including the reaction of species with the carrier at the feed-membrane interface, diffusion across the membrane and stripping at the membrane-strip interface. According to the literature, the flux of species $(J)$ can be found by disregarding the concentration of germanium in the strip phase with respect to Equation (1) [16]:

$$
J=P_{f} C_{f}
$$

In this equation, $P_{f}$ and $C_{f}$ represent the permeability coefficient at the feed-membrane interface and the ions concentration in the feed phase, respectively. Furthermore, the flux can be written according to Fick's first law in a differential form as Equation (2):

$$
J=-\frac{V}{A}\left(\frac{d C_{f}}{d t}\right)
$$

where $V$ and $A$ are the volume of the feed phase and the membrane efficient area, respectively. With respect to Equation (1), the integration form of Equation (2) can be written as Equation (3):

$$
\ln \left(C_{f, 0} / C_{f . t}\right)=-\frac{A P_{f} t}{V}
$$


where $C_{f, 0}$ and $C_{f, t}$ depict the concentration of ions in the feed phase at the initial time and time of ' $t$ ', respectively. Hence, the permeability coefficient can be evaluated from the slope corresponding to the plot of $\ln \left(C_{f, 0} / C_{f . t}\right)$ against $t$. Furthermore, the transport efficiency (\%T) of germanium is calculated as Equation (4):

$$
\% T=\frac{C_{f, t}}{C_{f, 0}} \times 100
$$

\section{Solution Chemistry}

Germanium dioxide can be dissolved in water. However, this dissolution is slowly carried out as an intermediate germanium tetra-hydroxide $\left(\mathrm{Ge}(\mathrm{OH})_{4}\right)$. These species can be converted to germanic acid with the solubility product $\left(K_{s p}\right)$ of $2.39 \times 10^{-4.5}$ as Equation (5) [29]:

$$
2 \mathrm{H}_{2} \mathrm{O}_{(a q)}+\mathrm{GeO}_{2} \leftrightharpoons \mathrm{Ge}(\mathrm{OH})_{4(a q)} \leftrightharpoons \mathrm{H}_{2} \mathrm{GeO}_{3(a q)}+\mathrm{H}_{2} \mathrm{O}_{(a q)}
$$

Germanium can form various complexes with organic acids such as tartaric acid, citric acid, oxalic acid, etc. Oxalic acid is a possible complexant which forms various complexes with germanium ion. According to the literature and observations, the solubility of germanium increases in the presence of oxalic acid [1]. The formation of germanium anionic and neutral species has been reported. For instance, Pokrovski et al. [30] described that germanium $(0.02 \mathrm{~mol} / \mathrm{L})$ and oxalic acid $(0.1 \mathrm{~mol} / \mathrm{L})$ form anionic species of $\mathrm{Ge}(\mathrm{OH})_{2}(\mathrm{ox})_{2}{ }^{2-}$ ("ox" depicts oxalate) at pHs below 7. Furthermore, Liu et al. [21] introduced $\mathrm{Ge}(\mathrm{ox})_{3}{ }^{2-}$ as an anionic complex of germanium and oxalic acid. The concentrations of germanium and oxalic acid in the latter study were reported to be 0.013 and $0.67 \mathrm{~mol} / \mathrm{L}$, respectively. However, others $[14,29]$ reported the formation of neutral species of trisoxalato germinates as Equation (6):

$$
3 \mathrm{H}_{2} \mathrm{C}_{2} \mathrm{O}_{4(a q)}+\mathrm{GeO}_{2(s)} \leftrightharpoons \mathrm{H}_{2} \mathrm{Ge}\left(\mathrm{C}_{2} \mathrm{O}_{4}\right)_{3(a q)}+2 \mathrm{H}_{2} \mathrm{O}_{(a q)}
$$

In the current study, germanium neutral species in the form of trisoxalato germinates have been considered as predominant species participated in the reactions. According to the literature review [23,31,32], the probable extraction reaction of germanium using Cyanex 923 can be written as Equation (7) [14]:

$$
2 \mathrm{H}^{+}{ }_{(a q)}+4 L_{(\text {org })}+\mathrm{Ge}\left(\mathrm{C}_{2} \mathrm{O}_{4}\right)_{3}{ }^{2-}{ }_{(a q)} \leftrightharpoons \mathrm{H}_{2} \mathrm{Ge}\left(\mathrm{C}_{2} \mathrm{O}_{4}\right)_{3} \cdot 4 L_{(\text {org })}
$$

\section{Results and Discussion}

\subsection{Determination of Appropriate Oxalic Acid Concentration in the Feed Phase}

With respect to the "solution chemistry" section, germanium was transported across FSSLM as a neutral complex (trisoxalato germinate) using Cyanex 923. The transport efficiency depends on the complexation of germanium with oxalate. Therefore, the concentration of oxalic acid is a significant parameter for transport. In this regard, a series of experiments were conducted at the oxalic acid concentration in the range of $0.05-0.2 \mathrm{~mol} / \mathrm{L}$ with the carrier concentration of $20 \% \mathrm{v} / \mathrm{v}$. Figure $2 \mathrm{a}, \mathrm{b}$ illustrates the obtained results. As can be seen in these figures, the transport efficiency and permeation coefficients decrease at lower and higher values of this range. Moreover, at the oxalic concentration of $0.075 \mathrm{~mol} / \mathrm{L}$, the maximum permeation coefficient and transport efficiency were found reaching the values of $9.97 \times 10^{-4} \mathrm{~cm} / \mathrm{s}$ and $88 \%$, respectively. The species of germanium for various oxalic acid concentrations have been illustrated in Figure 3. As can be seen in this figure, at very low oxalic acid concentrations, the dissociation of oxalic acid $\left(\mathrm{H}_{2} \mathrm{Ox}\right)$ is not complete and the germanium tetra-hydroxide $\left(\mathrm{Ge}(\mathrm{OH})_{4}\right)$ is the predominant compound. However, by increasing the oxalic acid concentration (up to $0.1 \mathrm{~mol} / \mathrm{L}$ ), the concentration of oxalate is enhanced and it promotes an increase in the $\mathrm{H}_{2} \mathrm{Ge}\left(\mathrm{C}_{2} \mathrm{O}_{4}\right)_{3}$ concentration and consequently the germanium transport improves. However, with 
more enhancement of oxalic acid concentration, the concentration of germanium oxalate decreases resulting in the decrease in the germanium transport at a higher oxalic acid concentration $(>0.1 \mathrm{~mol} / \mathrm{L})$.
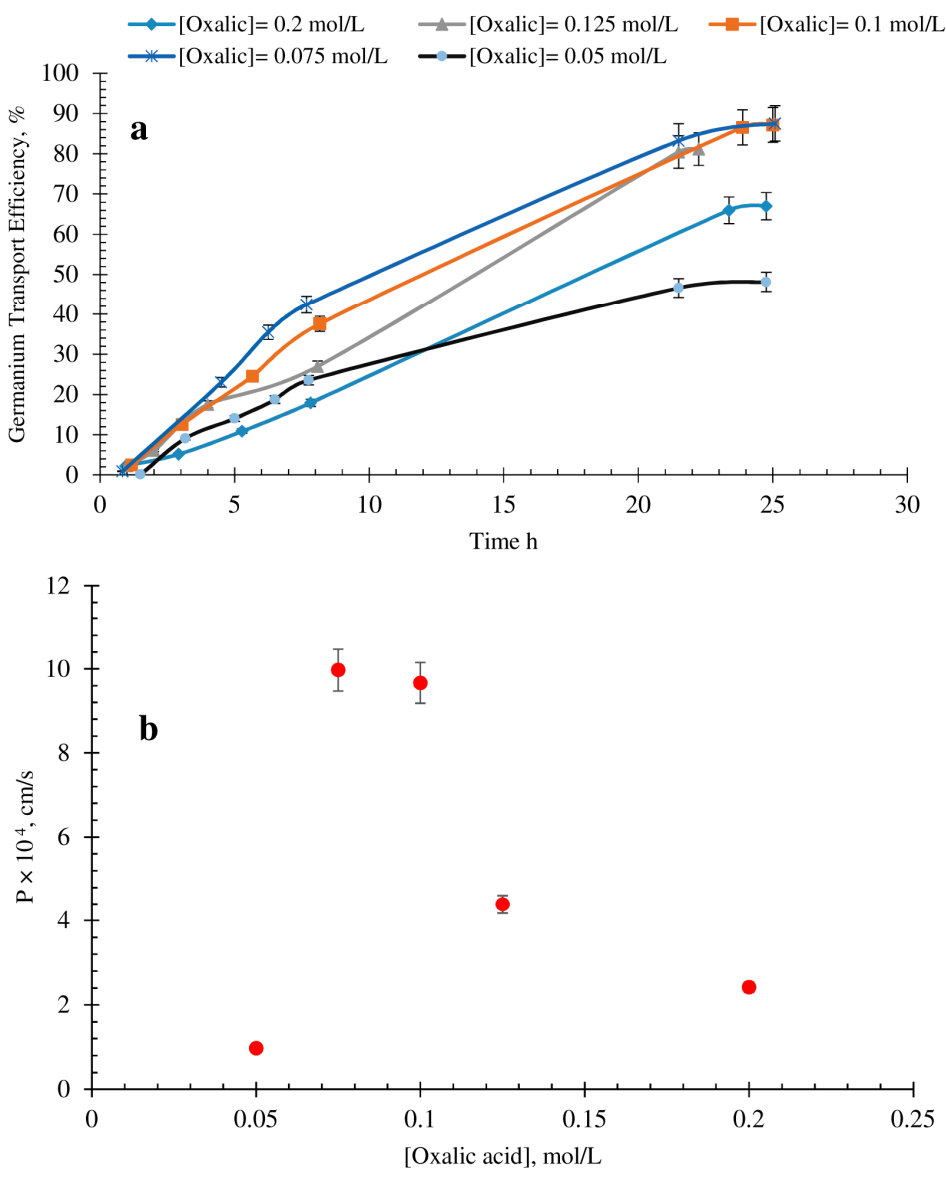

Figure 2. The effect of oxalic acid concentration on (a) transport and (b) permeability coefficient of germanium on the FSSLM system ([Cyanex 923] $=20 \% \mathrm{v} / \mathrm{v}$, temperature of $22{ }^{\circ} \mathrm{C}$, and $[\mathrm{NaOH}]=0.1 \mathrm{~mol} / \mathrm{L})$.

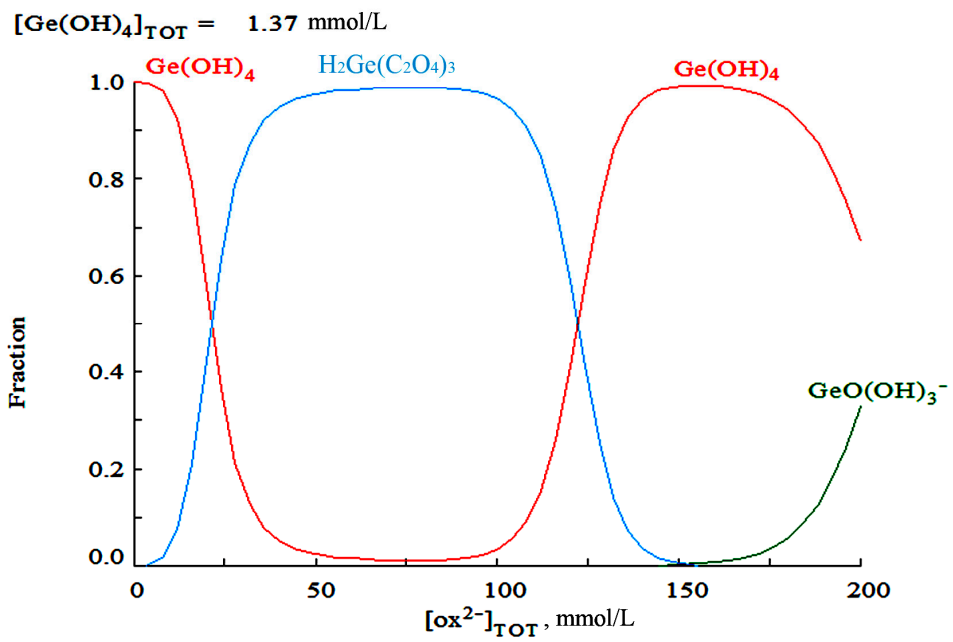

Figure 3. Species of germanium in various oxalic acid concentrations and $100 \mathrm{mg} / \mathrm{L} \mathrm{Ge}$ (calculated by Medusa software, KTH university, Stockholm, Sweden). 


\subsection{Evaluation of Appropriate Carrier Concentration}

The presence of mobile carriers in a membrane phase is necessary for the transport phenomena; however, an excess amount enhances the viscosity and decreases transport [33]. Therefore, in order to obtain efficient transport, determining an optimum concentration of the carrier is important. In the present study, taking in count the results from solvent extraction experiments, the range of $0-30 \% \mathrm{v} / \mathrm{v}$ for the Cyanex 923 concentration was selected. All FSSLM experiments were done with $0.075 \mathrm{~mol} / \mathrm{L}$ of oxalic acid, at temperature of $22^{\circ} \mathrm{C}$, and using $0.1 \mathrm{~mol} / \mathrm{L}$ of $\mathrm{NaOH}$ as a receiving solution. According to the result plotted in Figure 4a,b, the complete reaction between Ge(IV) species and carrier molecules does not occur at lower concentrations of the carrier. The germanium transport efficiency rises to about $88 \%$ when carrier concentration increases from $10 \% \mathrm{v} / \mathrm{v}$ to $20 \% \mathrm{v} / \mathrm{v}$. Moreover, with increasing carrier concentration, the curves corresponding to Cyanex 923 of 30 and $25 \% \mathrm{v} / \mathrm{v}$ are shifted down, showing the decrease in germanium transport. In Figure $4 \mathrm{~b}$, this behavior can be observed in the reduction of the permeability coefficient. The mentioned reduction may be due to the enhancement of viscosity resulted from the increase in Cyanex 923 concentration and its precipitation in pores of the membrane [34]. According to the aforementioned discussion, the concentration of $20 \% \mathrm{v} / \mathrm{v}$ is selected as the optimum carrier concentration.
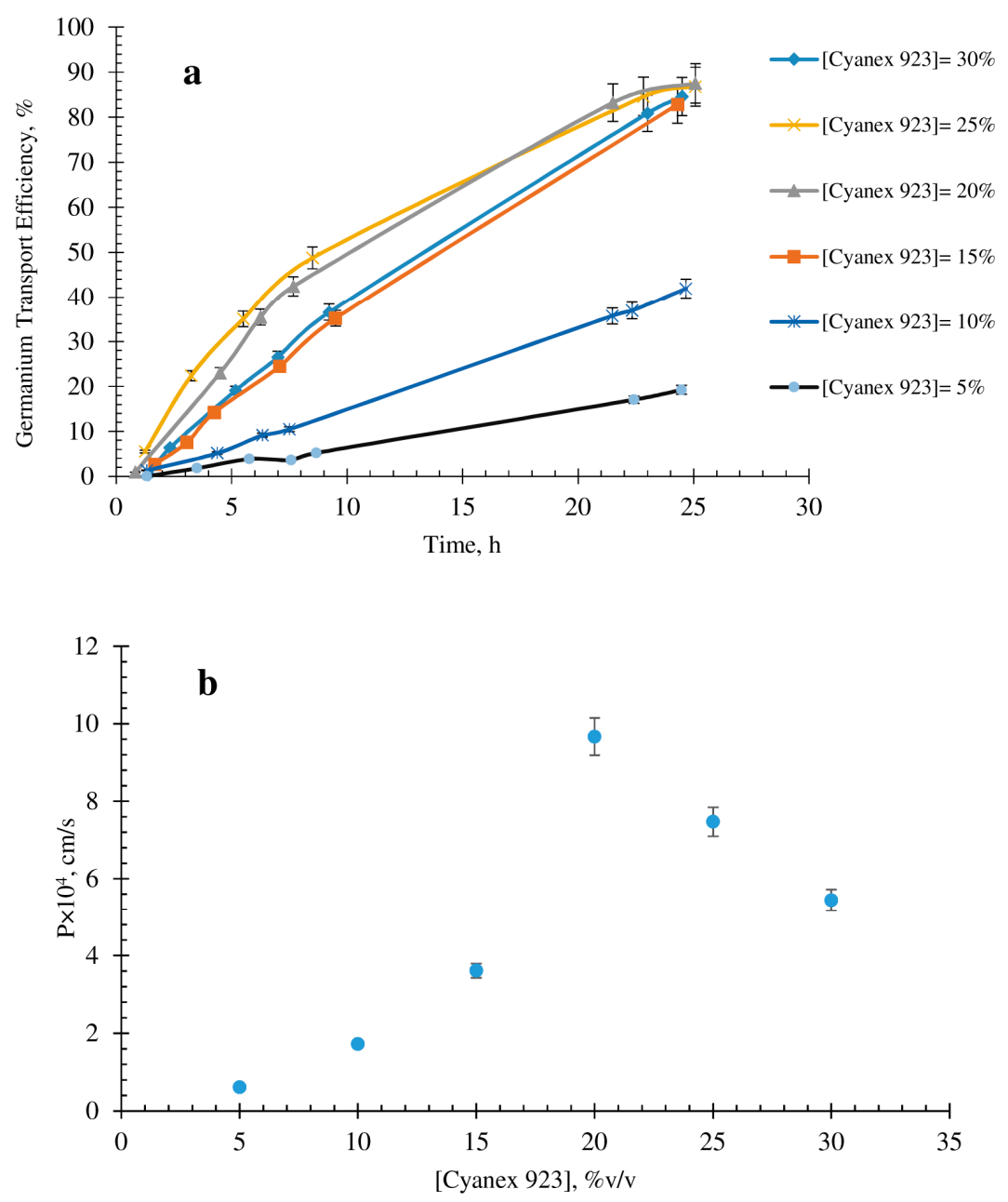

Figure 4. Effect of the carrier concentration on (a) transport and (b) permeability coefficient of germanium on the FSSLM system ([Oxalic acid] $=0.075 \mathrm{~mol} / \mathrm{L}$, temperature of $22{ }^{\circ} \mathrm{C}$, and $[\mathrm{NaOH}]=0.1 \mathrm{~mol} / \mathrm{L})$. 


\subsection{Effect of $\mathrm{NaOH}$ Concentration as a Strip Reagent on Germanium Transport}

Stripping is an important reaction that takes place in the membrane-strip phase boundary layer on an SLM. For this reaction to occur, the selection of an appropriate striping reagent-a chemical substance such as an acid or a base-is important. To select efficient reagent/reagents for stripping germanium from the loaded organic carrier, a series of liquid-liquid extraction experiments were carried out, and the results have been published elsewhere [14]. Among several reagents such as ammonium chloride $\left(\mathrm{NH}_{4} \mathrm{Cl}\right)$, sodium hydroxide $(\mathrm{NaOH})$, catechol $\left(\mathrm{C}_{6} \mathrm{H}_{6} \mathrm{O}_{2}\right)$, citric acid $\left(\mathrm{C}_{6} \mathrm{H}_{8} \mathrm{O}_{7}\right)$, ammonia $\left(\mathrm{NH}_{3}\right)$, sodium sulfate $\left(\mathrm{Na}_{2} \mathrm{SO}_{4}\right)$, and sulfuric acid $\left(\mathrm{H}_{2} \mathrm{SO}_{4}\right), \mathrm{NaOH}$ was selected because it is the most efficient reagent for stripping germanium from 20\% v/v Cyanex 923 . Therefore, FSSLM experiments were carried out to evaluate the effect of the $\mathrm{NaOH}$ concentration on the germanium transport using the carrier concentration of $20 \% \mathrm{v} / \mathrm{v}$ Cyanex 923 and an oxalic acid concentration of $0.075 \mathrm{~mol} / \mathrm{L}$ in the feed solution. The results can be seen in Figure $5 \mathrm{a}, \mathrm{b}$.
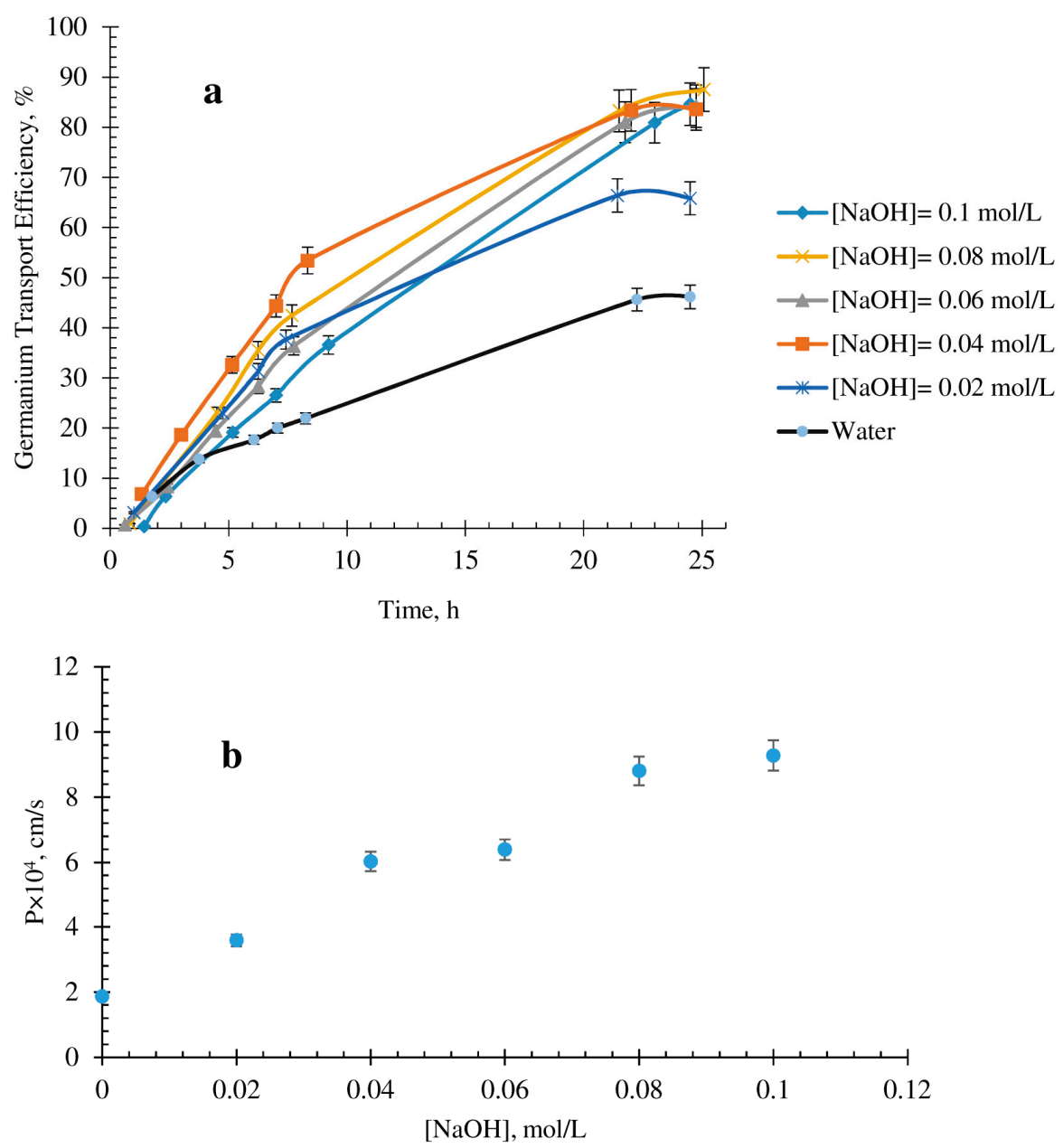

Figure 5. Effect of $\mathrm{NaOH}$ concentration on (a) transport and (b) permeability coefficient of germanium on the FSSLM system ([Oxalic acid] $=0.075 \mathrm{~mol} / \mathrm{L}$, temperature of $22{ }^{\circ} \mathrm{C}$, and [Cyanex 923] = 20\% v/v).

As can be seen in these figures, the transport efficiency and the permeability coefficient increase with an enhancement of $\mathrm{NaOH}$ concentration. About $87 \%$ of germanium was transferred to the strip phase at concentrations in the range of $0.04-0.1 \mathrm{~mol} / \mathrm{L} \mathrm{NaOH}$. The transport efficiency corresponding to the $\mathrm{NaOH}$ concentration of $0.02 \mathrm{~mol} / \mathrm{L}$ is approximately $66 \%$. Furthermore, according to Figure $5 \mathrm{~b}$, the permeability coefficient rises to $9.28 \times 10^{-4} \mathrm{~cm} / \mathrm{s}$ at the $\mathrm{NaOH}$ concentration of $0.1 \mathrm{~mol} / \mathrm{L}$. This is due to the increase in the amount of $\mathrm{OH}^{-}$anions which enhances the de-complexation rate at the 
interface of the strip side [31]. The probable reaction for stripping species from the loaded carrier can be written as Equation (8) [14]:

$$
\mathrm{H}_{2} \mathrm{Ge}\left(\mathrm{C}_{2} \mathrm{O}_{4}\right)_{3} \cdot 4 \mathrm{~L}_{(\text {org })}+2 \mathrm{OH}^{-} \leftrightharpoons 4 \mathrm{~L}_{(\text {org })}+\mathrm{Ge}\left(\mathrm{C}_{2} \mathrm{O}_{4}\right)_{3}{ }^{2-}{ }_{(\text {aq })}+2 \mathrm{H}_{2} \mathrm{O}_{(\text {org })}
$$

\subsection{Effect of Membrane Type on Germanium Transport}

To know the effect of membrane type on the transport of germanium, an experiment was conducted at the condition of $100 \mathrm{mg} / \mathrm{L} \mathrm{Ge}$, oxalic acid of $0.075 \mathrm{~mol} / \mathrm{L}$, and $0.1 \mathrm{~mol} / \mathrm{L}$ of $\mathrm{NaOH}$. For this experiment, a polyvinylidene difluoride (PVDF) membrane support was used.

As seen in Figure 6, there is not a significant difference between the transport efficiencies corresponding to the PTFE and PVDF membranes obtained from the experiments carried out under a similar condition. However, the overall transport efficiency of the PTFE membrane is somewhat greater than that of PVDF. The values of the germanium permeability coefficients of the PVDF and PTFE membranes were found to be $3.14 \times 10^{-4}$ and $9.28 \times 10^{-4} \mathrm{~cm} / \mathrm{s}$, respectively. Therefore, the germanium permeability through the PTFE membrane is approximately three times that through PVDF. Similar results have been reported by Adnan et al. [35]. Various parameters such as higher tortuosity of PVDF membrane result in reducing their permeability [36].

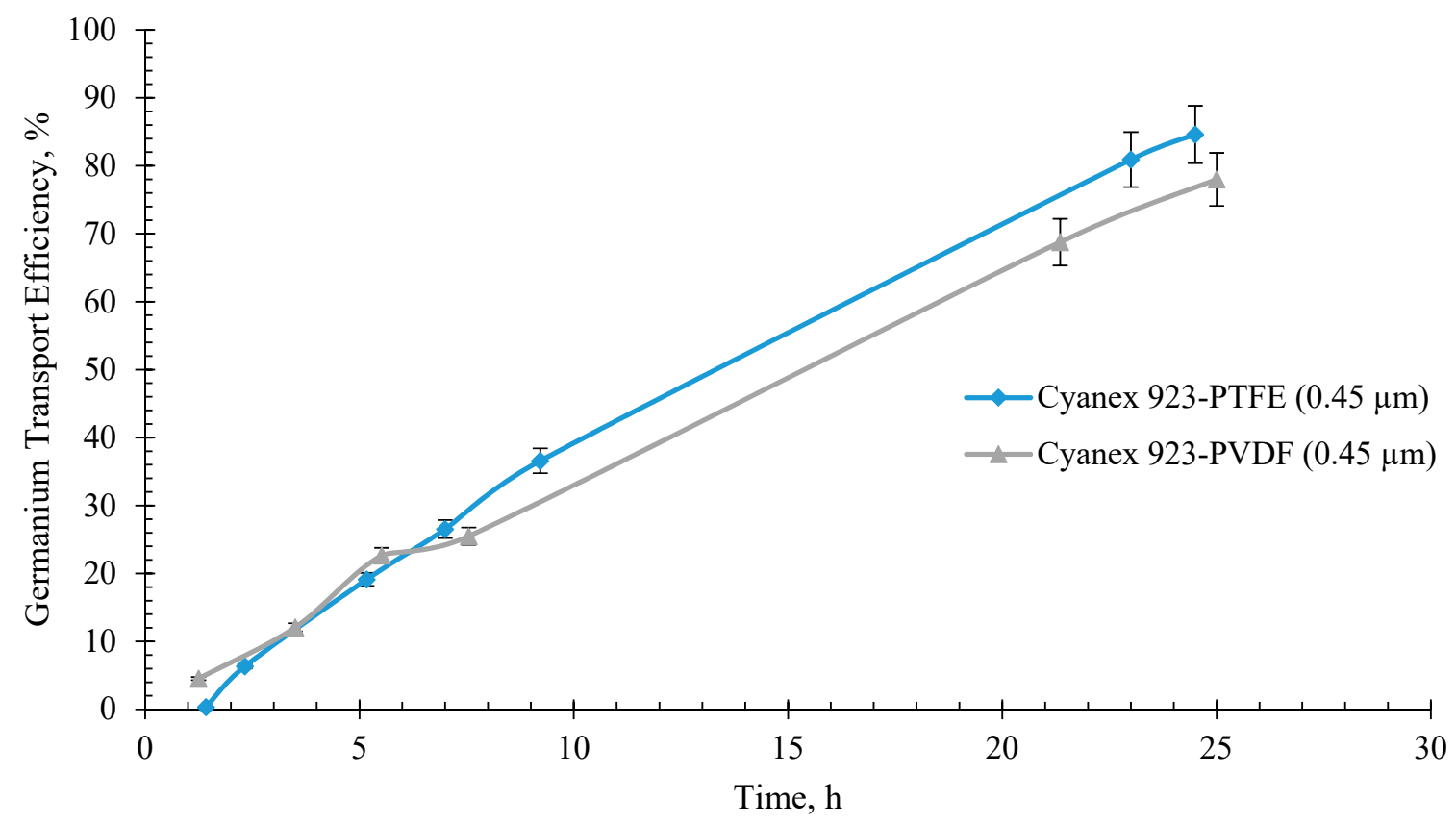

Figure 6. Transport efficiency of germanium through polytetrafluoroethylene (PTFE) and polyvinylidene difluoride (PVDF) membranes versus time ([Oxalic acid] $=0.075 \mathrm{~mol} / \mathrm{L}$, temperature of $22{ }^{\circ} \mathrm{C}$, [Cyanex 923] $=20 \% \mathrm{v} / \mathrm{v}$, and $\left.[\mathrm{NaOH}]=0.1 \mathrm{~mol} / \mathrm{L}\right)$.

\subsection{Permeability Model}

The permeation of germanium ions through the FSSLM (with the PTFE membrane) was modeled to find the mass transfer resistances. To model the mentioned system, it was assumed that species transport through SLM was done with diffusion and the chemical reactions took place instantly [37]. Figure 7 illustrates how germanium oxalate permeates through a PTFE membrane containing Cyanex 923 based on the following steps:

(i) In the feed phase, germanium oxalate and protons diffuse to the interface layer.

(ii) Diffused species and Cyanex 923 molecules react together in the mentioned layer.

(iii) The produced complexes permeate across the membrane toward the membrane-strip interface layer. 
(iv) $\mathrm{NaOH}$ detaches germanium-Cyanex 923 complexes at the membrane-strip phase interface. Therefore, germanium species are stripped from the organic carrier.

(v) The unloaded carrier molecules permeate inversely toward the feed phase.

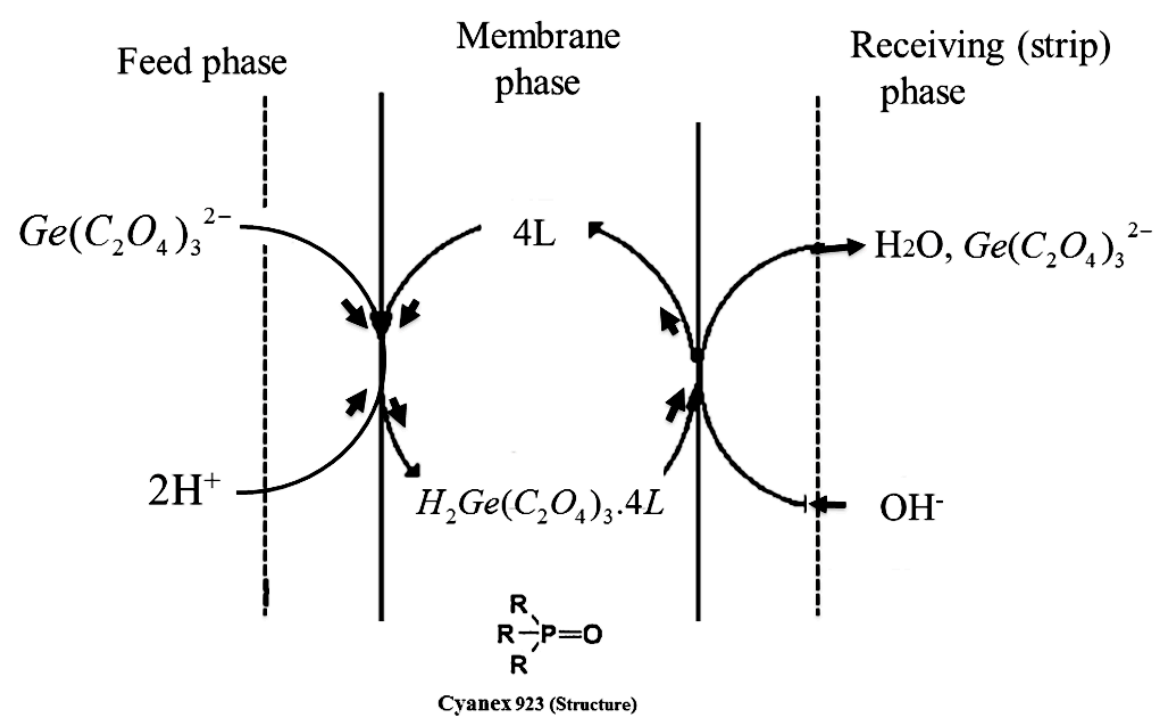

Figure 7. A schematic transport of germanium ion through FSSLM-Cyanex923.

The extraction reaction of germanium by Cyanex 923 has been described in Equation (7). According to an LLX model developed by Haghighi et al. [38], the extraction equilibrium constant of the aforementioned reaction was calculated to be 2056. The germanium flux can be obtained using Fick's first diffusion law. Hence, the fluxes at the feed-membrane boundary layer and the membrane phase ( $J_{f}$ and $J_{m}$, respectively) can be presented as Equations (9) and (10):

$$
\begin{gathered}
J_{f}=\frac{1}{\Delta_{f}}\left([G e(I V)]_{f}-[G e(I V)]_{b l, f}\right) \\
J_{m}=\frac{1}{\Delta_{m}}\left(\left[\mathrm{H}_{2} \mathrm{Ge}(o x)_{3} \cdot 4 R\right]_{b l, f}-\left[\mathrm{H}_{2} \mathrm{Ge}(o x)_{3} \cdot 4 R\right]_{b l, s}\right)
\end{gathered}
$$

where $\Delta_{m}$ and $\Delta_{f}$ depict the resistances corresponding to the membrane phase and the feed phase boundary layer, respectively. Subscripts $f, b l$, and $s$ are feed, boundary layer, and strip, respectively. Moreover, $[\mathrm{Ge}(\mathrm{IV})]_{\mathrm{f}},\left[\mathrm{H}_{2} \mathrm{Ge}(\mathrm{ox})_{3} .4 R\right]_{b l, f}$, and $\left[\mathrm{H}_{2} \mathrm{Ge}(o x)_{3} .4 R\right]_{b l, s}$ represent the germanium concentrations in the feed phase, the feed-membrane, and the strip-membrane boundary layers, respectively. It is noted that since the germanium concentration in the strip-membrane boundary layer is lower than that in the feed-membrane boundary layer, $\left[\mathrm{H}_{2} \mathrm{Ge}(o x)_{3} \cdot 4 R\right]_{b l, s}$ has been neglected. Hence, Equation (10) can be rewritten as Equation (11):

$$
J_{m}=\frac{1}{\Delta_{m}}\left(\left[H_{2} G e(o x)_{3} \cdot 4 R\right]_{b l, f}\right)
$$

Since the chemical reactions took place instantly, the flux values in the feed-membrane layer and the membrane phase are equal $\left(J_{f}=J_{m}=J\right)$. Therefore, overall $J$ can be found as Equation (12):

$$
J=\frac{K\left[H^{+}\right]^{2}[R]_{\text {org }}{ }^{4}[G e(I V)]_{f}}{\Delta_{m}+\Delta_{f}\left(K\left[H^{+}\right]_{\text {aq }}^{2}[R]_{\text {org }}^{4}\right)}
$$


Regarding Equation (1), the permeability coefficient is also written as Equation (13):

$$
P=\frac{K\left[H^{+}\right]^{2}[R]_{\text {org }}{ }^{4}}{\Delta_{m}+\Delta_{f}\left(K\left[H^{+}\right]_{\text {aq }}^{2}[R]_{\text {org }}^{4}\right)}
$$

By arranging Equation (13), Equation (14) allows us to obtain the mass transfer resistances:

$$
\frac{1}{P}=\Delta_{f}+\frac{\Delta_{m}}{\left(K\left[H^{+}\right]_{a q}^{2}[R]_{o r g}^{4}\right)}
$$

By plotting $\frac{1}{\left(K\left[H^{+}\right]_{a q}^{2}[R]_{o r g}^{4}\right)}$ versus $1 / P$, a straight line is obtained.

The intercept and the slope values of this line were used to determine $\Delta_{f}$ and $\Delta_{m}$, respectively This plot is shown in Figure 8. According to the plot, the values of 1 and $1345 \mathrm{~s} / \mathrm{cm}$ were found for $\Delta_{m}$ and $\Delta_{f}$, respectively.

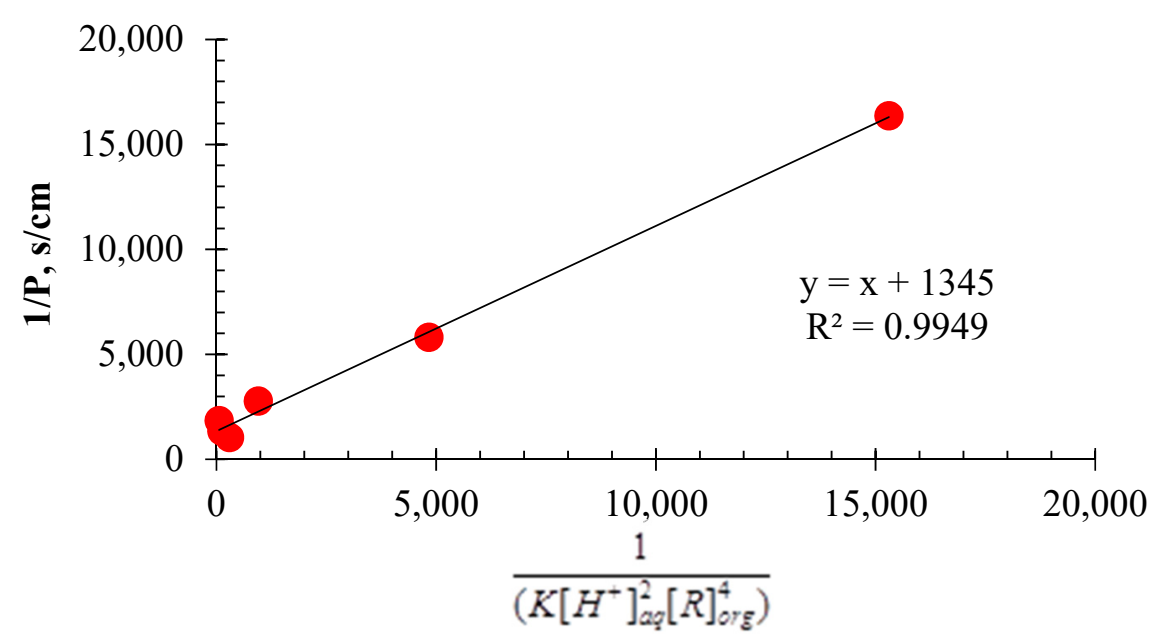

Figure 8. The plot of $1 / P$ vs. $\frac{\left[H^{+}\right]^{4}}{\left(K[R]_{\text {org }}^{4}\right)}([\mathrm{Ge}]=100 \mathrm{mg} / \mathrm{L}$, [Oxalic acid $]=0.075 \mathrm{~mol} / \mathrm{L}$, temperature of $22{ }^{\circ} \mathrm{C}$, and $\left.[\mathrm{NaOH}]=0.1 \mathrm{~mol} / \mathrm{L}\right)$.

\section{Conclusions}

This paper focuses on studying the transport of germanium(IV) through an FSSLM using Cyanex 923 as a carrier. The main finding of this study is that germanium and oxalate can form neutral species that can be extracted and transported by Cyanex 923 through an FSSLM system. Results show that the oxalic acid concentration is an essential parameter for the germanium transport because extractable germanium oxalate species can also form in a limited range of oxalate concentration. An optimum concentration of oxalic acid for the complete transport of germanium is in the range of $0.075-0.1 \mathrm{~mol} / \mathrm{L}$. The appropriate Cyanex 923 concentration in the liquid membrane phase for the complete germanium transport is $20 \% \mathrm{v} / \mathrm{v}$. Due to the opposite effect of the viscosity at the higher concentrations of Cyanex 923 on germanium transport, the concentrations over $20 \% \mathrm{v} / \mathrm{v}$ are unsuitable for an effective process. In strip solutions with $\mathrm{NaOH}$ concentrations of $0.04-0.1 \mathrm{~mol} / \mathrm{L}$, the maximum germanium transport is achieved. Finally, a permeation model was developed to find the mass transfer resistances. As a result, the values of 1 and $1345 \mathrm{~s} / \mathrm{cm}$ were found for $\Delta_{m}$ and $\Delta_{f}$, respectively.

Author Contributions: H.K.H. made a significant contribution to every stage of this paper, such as the investigation, analysis, methodology and visualization. M.I. contributed to the conceptualization, project administration, validation and supervision of the paper. M.T.C. contributed to the investigation for the paper. A.M.S. contributed to the funding acquisition, investigation and resources provision for the paper. M.I. and H.K.H. finalized the paper by a critical revision. 
Funding: This research was partially funded by THE SPANISH MINISTRY OF ECONOMY AND COMPETITIVENESS, MINECO, grant number CTM2017-83581-R.

Acknowledgments: This research was implemented in the Department of Chemical Engineering, Universitat Politècnica de Catalunya (Barcelona-Tec), Spain. The authors acknowledge Agustin Fortuny for his help. This work has been partially supported by the Spanish Ministry of Economy and Competitiveness, MINECO, through the grant number CTM2017-83581-R.

Conflicts of Interest: The authors declare no conflict of interest.

\section{References}

1. Liu, F.; Liu, Z.; Li, Y.; Wilson, B.P.; Lundström, M. Recovery and separation of gallium(III) and germanium(IV) from zinc refinery residues: Part I: Leaching and iron(III) removal. Hydrometallurgy 2017, 169, 564-570. [CrossRef]

2. Zhang, L.; Xu, Z. Application of vacuum reduction and chlorinated distillation to enrich and prepare pure germanium from coal fly ash. J. Hazard. Mater. 2017, 321, 18-27. [CrossRef] [PubMed]

3. Arroyo, F.; Fernández-Pereira, C. Hydrometallurgical recovery of germanium from coal gasification fly ash. Solvent extraction method. Ind. Eng. Chem. Res. 2008, 47, 3186-3191. [CrossRef]

4. Liu, F.; Liu, Z.; Li, Y.; Liu, Z.; Li, Q.; Zeng, L. Extraction of gallium and germanium from zinc refinery residues by pressure acid leaching. Hydrometallurgy 2016, 164, 313-320. [CrossRef]

5. Torralvo, F.A.; Fernández-Pereira, C. Recovery of germanium from real fly ash leachates by ion-exchange extraction. Min. Eng. 2011, 24, 35-41. [CrossRef]

6. Arroyo, F.; Font, O.; Fernández-Pereira, C.; Querol, X.; Juan, R.; Ruiz, C.; Coca, P. Germanium recovery from gasification fly ash: Evaluation of end-products obtained by precipitation methods. J. Hazard. Mater. 2009, 167, 582-588. [CrossRef]

7. Hernández-Expósito, A.; Chimenos, J.M.; Fernández, A.I.; Font, O.; Querol, X.; Coca, P.; García Peña, F. Ion flotation of germanium from fly ash aqueous leachates. Chem. Eng. J. 2006, 118, 69-75. [CrossRef]

8. Kuroiwa, K.; Ohura, S.-I.; Morisada, S.; Ohto, K.; Kawakita, H.; Matsuo, Y.; Fukuda, D. Recovery of germanium from waste solar panels using ion-exchange membrane and solvent extraction. Min. Eng. 2014, 55, 181-185. [CrossRef]

9. Cui, W.; Wang, S.; Peng, J.; Zhang, L.; Zhang, G. Catechol-functionalized nanosilica for adsorption of germanium ions from aqueous media. J. Sol-Gel Sci. Technol. 2016, 77, 666-674. [CrossRef]

10. Arroyo, F.; Pereira, C.; Bermejo, P. Demonstration Plant Equipment Design and Scale-Up from Pilot Plant of a Leaching and Solvent Extraction Process. Minerals 2015, 5, 298-313. [CrossRef]

11. Kamran Haghighi, H.; Irannajad, M.; Fortuny, A.; Sastre, A.M. Non-dispersive selective extraction of germanium from fly ash leachates using membrane-based processes. Sep. Sci. Technol. 2019, 1-16. [CrossRef]

12. Kamran Haghighi, H.; Irannajad, M.; Fortuny, A.; Sastre, A.M. Selective separation of Germanium(IV) from simulated industrial leachates containing heavy metals by non-dispersive ionic extraction. Min. Eng. 2019, 137, 344-353. [CrossRef]

13. Kamran Haghighi, H.; Irannajad, M.; Fortuny, A.; Sastre, A.M. Mathematical modeling for facilitated transport of Ge(IV) through supported liquid membrane containing Alamine 336. Chem. Pap. 2018, 72, 955-970. [CrossRef]

14. Kamran Haghighi, H.; Irannajad, M.; Fortuny, A.; Sastre, A.M. Recovery of germanium from leach solutions of fly ash using solvent extraction with various extractants. Hydrometallurgy 2018, 175, 164-169. [CrossRef]

15. Leepipatpiboon, N.; Pancharoen, U.; Ramakul, P. Separation of Co(II) and Ni(II) from thiocyanate media by hollow fiber supported liquid membrane containing Alamine300 as carrier-Investigation on polarity of diluent and membrane stability. Korean J. Chem. Eng. 2013, 30, 194-200. [CrossRef]

16. Ruhela, R.; Panja, S.; Sharma, J.N.; Tomar, B.S.; Tripathi, S.C.; Hubli, R.C.; Suri, A.K. Facilitated transport of $\mathrm{Pd}(\mathrm{II})$ through a supported liquid membrane (SLM) containing $\mathrm{N}, \mathrm{N}, \mathrm{N}^{\prime}, \mathrm{N}^{\prime}$-tetra-(2-ethylhexyl) thiodiglycolamide T(2EH)TDGA: A novel carrier. J. Hazard. Mater. 2012, 229-230, 66-71. [CrossRef] [PubMed] 
17. Kamran Haghighi, H.; Irannajad, M.; Moradkhani, D. Permeation and modeling studies on Ge(IV) facilitated transport using trioctylamine through supported liquid membrane. Korean J. Chem. Eng. 2017. [CrossRef]

18. Prakorn, R.; Eakkapit, S.; Weerawat, P.; Milan, H.; Ura, P. Permeation study on the hollow-fiber supported liquid membrane for the extraction of Cobalt(II). Korean J. Chem. Eng. 2006, 23, 117-123. [CrossRef]

19. Zaheri, P.; Abolghasemi, H.; Mohammadi, T.; Maraghe, M.G. Synergistic extraction and separation of Dysprosium and Europium by supported liquid membrane. Korean J. Chem. Eng. 2015, 32, 1642-1648. [CrossRef]

20. Yakabe, K.; Minami, S.-I. Liquid-Liquid Extraction of Germanium(IV) with Trioctylamine from Aqueous Oxalic Acid Solution. Nippon Kagaku Kaishi 1981, 1981,969-973. [CrossRef]

21. Liu, F.; Liu, Z.; Li, Y.; Wilson, B.P.; Liu, Z.; Zeng, L.; Lundström, M. Recovery and separation of gallium(III) and germanium(IV) from zinc refinery residues: Part II: Solvent extraction. Hydrometallurgy 2017, 171, 149-156. [CrossRef]

22. Urtiaga, A.M.; Ortiz, I. Extraction of Phenol Using Trialkylphosphine Oxides (Cyanex 923) in Kerosene. Sep. Sci. Technol. 1997, 32, 1157-1162. [CrossRef]

23. Rathore, N.S.; Leopold, A.; Pabby, A.K.; Fortuny, A.; Coll, M.T.; Sastre, A.M. Extraction and permeation studies of Cd(II) in acidic and neutral chloride media using Cyanex 923 on supported liquid membrane. Hydrometallurgy 2009, 96, 81-87. [CrossRef]

24. Alguacil, F.J.; López-Delgado, A.; Alonso, M.; Sastre, A.M.a. The phosphine oxides Cyanex 921 and Cyanex 923 as carriers for facilitated transport of chromium (VI)-chloride aqueous solutions. Chemosphere 2004, 57, 813-819. [CrossRef] [PubMed]

25. Alguacil, F.J.; Martínez, S. Solvent extraction of Zn(II) by Cyanex 923 and its application to a solid-supported liquid membrane system. J. Chem. Technol. Biotechnol. 2001, 76, 298-302. [CrossRef]

26. Alguacil, F.J.; Martínez, S. Permeation of iron(III) by an immobilised liquid membrane using Cyanex 923 as mobile carrier. J. Membr. Sci. 2000, 176, 249-255. [CrossRef]

27. Alguacil, F.J.; Coedo, A.G.; Dorado, M.T.; Padilla, I. Phosphine oxide mediate transport: Modelling of mass transfer in supported liquid membrane transport of gold (III) using Cyanex 923. Chem. Eng. Sci. 2001, 56, 3115-3122. [CrossRef]

28. Singh, S.K.; Misra, S.K.; Tripathi, S.C.; Singh, D.K. Studies on permeation of uranium (VI) from phosphoric acid medium through supported liquid membrane comprising a binary mixture of PC88A and Cyanex 923 in n-dodecane as carrier. Desalination 2010, 250, 19-25. [CrossRef]

29. McCrory-Joy, C. Electrolytic and chemical precipitation of germanium dioxide from oxalate solution. Electrochim. Acta 1985, 30, 51-55. [CrossRef]

30. Pokrovski, G.S.; Martin, F.; Hazemann, J.-L.; Schott, J. An X-ray absorption fine structure spectroscopy study of germanium-organic ligand complexes in aqueous solution. Chem. Geol. 2000, 163, 151-165. [CrossRef]

31. Arslan, G.; Tor, A.; Muslu, H.; Ozmen, M.; Akin, I.; Cengeloglu, Y.; Ersoz, M. Facilitated transport of Cr(VI) through a novel activated composite membrane containing Cyanex 923 as a carrier. J. Membr. Sci. 2009, 337, 224-231. [CrossRef]

32. Nosrati, S.; Jayakumar, N.S.; Hashim, M.A. Extraction performance of chromium (VI) with emulsion liquid membrane by Cyanex 923 as carrier using response surface methodology. Desalination 2011, 266, 286-290. [CrossRef]

33. Bhatluri, K.K.; Manna, M.S.; Ghoshal, A.K.; Saha, P. Supported liquid membrane based removal of lead(II) and cadmium(II) from mixed feed: Conversion to solid waste by precipitation. J. Hazard. Mater. 2015, 299, 504-512. [CrossRef] [PubMed]

34. Przewoźna, M.; Gajewski, P.; Michalak, N.; Bogacki, M.B.; Skrzypczak, A. Determination of the Percolation Threshold for the Oxalic, Tartaric, and Lactic Acids Transport through Polymer Inclusion Membranes with 1-Alkylimidazoles as a Carrier. Sep. Sci. Technol. 2014, 49, 1745-1755. [CrossRef]

35. Adnan, S.; Hoang, M.; Wang, H.; Xie, Z. Commercial PTFE membranes for membrane distillation application: Effect of microstructure and support material. Desalination 2012, 284, 297-308. [CrossRef]

36. Zhang, J.; Duke, M.; Ostarcevic, E.; Dow, N.; Gray, S.; Li, J.-d. Performance of new generation membrane distillation membranes. Water Sci. Technol. Water Supply 2009, 9, 501-508. [CrossRef] 
37. Alonso, M.; López-Delgado, A.; Sastre, A.M.; Alguacil, F.J. Kinetic modelling of the facilitated transport of cadmium (II) using Cyanex 923 as ionophore. Chem. Eng. J. 2006, 118, 213-219. [CrossRef]

38. Kamran Haghighi, H.; Irannajad, M.; Sastre, A.M. Germanium transport across supported liquid membrane with Cyanex 923: Mathematical modeling. Trans. Nonferrous Met. Soc. China 2019. accepted.

(C) 2019 by the authors. Licensee MDPI, Basel, Switzerland. This article is an open access article distributed under the terms and conditions of the Creative Commons Attribution (CC BY) license (http://creativecommons.org/licenses/by/4.0/). 